Golpour I, Nejad MZ, Chayjan RA, Nikbakht AM, Guiné RPF, Dowlati M. (2017) Investigating shrinkage and moisture diffusivity of melon seed in a microwave assisted thin layer fluidized bed dryer. Journal of Food Measurement and

Characterization. 11(1). 1-11.

\title{
Investigating shrinkage and moisture diffusivity of melon seed in a microwave assisted thin layer fluidized bed dryer
}

\author{
Iman Golpour,", Moein Zarrin Nejad², Reza Amiri Chayjan², Ali Mohammad \\ Nikbakht $^{3}$, Raquel P. F. Guiné ${ }^{4}$, Majid Dowlati ${ }^{5}$
}

${ }^{1}$ Young Researchers and Elite Club, Urmia Branch, Islamic Azad University, Urmia, Iran

${ }^{2}$ Department of Biosystems Engineering, Faculty of Agriculture, Bu-Ali Sina University, Hamedan, Iran

${ }^{3}$ Department of Mechanics of Biosystems, Faculty of Agriculture, Urmia University, Urmia, Iran

${ }^{4}$ CI\&DETS, Polytechnic Institute of Viseu, Portugal / CERNAS, Polytechnic Institute of Coimbra, Portugal

${ }^{5}$ Department of Mechanical Engineering of Biosystems, Faculty of Agriculture, University of Jiroft, Jiroft, Iran

*Corresponding Author: Iman Golpour; E-mail address: Imangolpour@gmail.com, Address: Urmia.Azad university, Tel: +98 4432719900; Fax: +98 4432755272

Short title: investigation of drying properties of melon seed

\section{Number of Figures: 5}

Number of Tables: 3 


\begin{abstract}
This work aimed to investigate the drying behavior of melon seed during combined fluidized bed-microwave drying system. Three drying air temperatures $\left(40,55\right.$ and $\left.70{ }^{\circ} \mathrm{C}\right)$, three microwave powers $(270,450$ and $630 \mathrm{~W})$ and three air velocities $(0.8,1.5$ and $2.3 \mathrm{~m} / \mathrm{s})$ were tested. Five mathematical models were selected to fit the experimental data for drying kinetics, and the results revealed that the Aghbashloo et al. model exhibited, in all cases, the best performance in fitting the experimental data $\left(\mathrm{R}^{2}\right.$ varying from 0.99088 to $0.99998 ; \chi^{2}$ from 0.00000 to 0.00185 and RMSE from 0.02289 to 0.82316 ). Calculated values of moisture diffusivity for dried melon seed varied from a minimum of $6.51 \times 10^{-10}$ to a maximum of $6.59 \times 10^{-9} \mathrm{~m}^{2} / \mathrm{s}$ under the tested drying conditions. Moisture diffusivity values increased as air temperature and microwave power was increased. Shrinkage values were calculated and found to vary in the range from $46.99 \%$ to $15.09 \%$.
\end{abstract}

Keywords Melon seed. Microwave fluidized bed drying. Moisture diffusivity. Shrinkage

\title{
Introduction
}

Melon seed (Colocynthis citrullus L.) is a common Nigerian oil seed containing roughly $50 \%$ by weight of oil, $28.4 \%$ protein (60\% of defatted flour), $2.7 \%$ fiber, $3.6 \%$ ash and $8.2 \%$ carbohydrate [1]. The seed is an excellent source of essential amino acids, particularly arginine, tryptophan and methionine, as well as vitamins $\mathrm{B}_{1}$ and $\mathrm{B}_{2}$, and niacin, and minerals, such as sulphur, calcium, magnesium, manganese, potassium, phosphorus, iron and zinc [2]. The oil obtained from the seeds is utilized for edible purposes [1], while the remaining cake is fried and used up as a snack. Containing mainly linoleic (62.8\%) and oleic (159\%) unsaturated fatty acids, the oil can be an available alternative to maize oil in diets intended to decrease high levels of blood cholesterol. Such perception of the product potential has led to an increase in the production of these seeds.

One major problem that besets melon seeds is that they deteriorate quickly during storage due to fungal infection [3]. The effect of fungal attack on melon seeds includes decreased nutritive value, change in colour, increase in the peroxide value, reduced seed germination 
and mycotoxin production [2]. The moisture content plays a vital role in the maintenance of seed shelf-life quality.

Dehydration refers to the moisture removal process, in which simultaneous heat and mass transfer occur. Moisture transfer can happen in two forms: surface evaporation and internal liquid vapor diffusion [4]. Drying is one of the most common used methods for food preservation, being the basic goal when drying food and agricultural products the elimination of moisture from the material down to a safe level to prevent deteriorative reactions and microbial spoilage [5]. Different methods of drying could have different bearings on the effective moisture diffusivity, shrinkage and other physical properties of the drying material. One of the most popular methods of drying materials with high moisture content is fluidized bed drying. This method offers the advantages of good mixing, high heat and mass transfer coefficients and hence increased drying rates resulting in shorter drying time [6].

However, all fluidized bed dryers, with or without the use of inert particles, have a common limit that is independent of the principal mode of heat transfer from the heating medium to the surface of the material, the transfer from the surface to the inside of the particle is principally by conduction and thus the process is slow. This phenomenon causes long drying time during the falling rate period in drying of food stuffs [7]. The alternative which has recently been widely employed is the use of rapid transfer of electromagnetic energy in the form of microwaves directly to the water molecules in the material in order to bypass the surface-to-center conduction stage. Because the waves can penetrate directly into the material, heating is volumetric (from inside out) and provides fast and uniform heating throughout the product. The quick absorption of energy by water molecules causes rapid evaporation of water, resulting in high drying rates of the food [8].

The application of microwaves solely can result in uneven heating of certain products depending on their dielectric and thermophysical properties [9-12]. This problem is more significant when processing at low frequencies, in which case the dielectric properties are considerably dependent on temperature variations. To overcome some of the limitations of single microwave or fluidized bed driers, one strategy is to combine microwave with a fluidized bed dryer. Temperature uniformity of the particles in the bed is provided by good mixing due to fluidization [13], and drying time is reduced by the use of microwave energy [8]. This method provides an effective way of overcoming the non-uniform heating problems in conventional pure microwave heating. Some researchers have recently focused on the microwave drying kinetics of foods, such as green pea [14] and chestnut corn [6]. Results of 
such studies elucidated that drying time under microwave convection would be reduced intensively compared to common convection methods.

Effective moisture diffusivity of food and agricultural products is strictly required for optimized design and construction of a dryer [15] and it represents the effect of all input parameters on the mass transfer in drying process [16]. Although much information has been reported on the modeling of drying kinetics and effective moisture diffusivity for various food and agricultural products, no experimental report has been divulged for melon seed.

An undesirable shape volumetric change associated with moisture diffusion is known as shrinkage. In general, shrinkage takes place as a result of volume reduction due to evaporation of the moisture contained in the drying sample. The changes in dimensions of the solid could be monitored in most cases. Shrinkage during drying is important not only from the viewpoint of product end-use but also for processing simulation [17]. Shrinkage of products such as broad beans [16] and papaya [18] has been reported.

In order to design and evaluate modern applicable microwave food processes, mathematical modeling of drying behavior of food stuffs is vital. To predict the drying behavior of food and agricultural material, many thin-layer drying mathematical models have been developed that fall onto three main categories: theoretical (Fick's second law of diffusion), semi theoretical (Lewis, Page, modified Page, Henderson-Pabis, logarithmic, Two-term, Two-term exponential, approximation of diffusion, Verma, etc.), and empirical (Wang-Singh). Air temperature and material characteristic dimension are greatly affected by drying kinetics in convective drying. These models are dependent only on drying time and constants, while influence of all other factors is negligible [16].

Any attempt to characterize the drying behavior of the materials, must inevitably address the physical parameters of the material such as shrinkage and moisture diffusivity. Due to insufficiency of information detailed on melon seed in the literature, this research was designed to investigate the drying behavior, the shrinkage properties and moisture diffusivity of melon seed during drying in a fluidized bed dryer combined with microwave at various levels of air velocity, power and temperature.

\section{Materials and Methods}

Sample Preparation 
Melon (Colocynthis citrullus L.) seeds used in the drying experiments were purchased from a local market in Hamedan, Iran. Foreign matter, broken and immature seeds were rejected and the good seeds for the work were manually unshelled. The seeds were packed in double layered low density polyethylene bags and then stored in a refrigerator at low temperature $\left(+4 \pm 1{ }^{\circ} \mathrm{C}\right)$ to avoid the growth of microorganisms and allowing to uniformity of moisture distribution [19-21]. The samples were mixed and their initial moisture content was

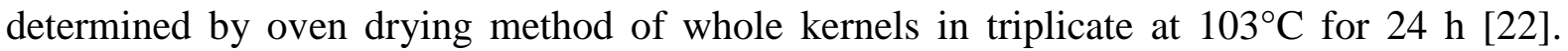
Three samples, each weighing $15 \mathrm{~g}$, were placed in this oven set. Initial moisture content of the melon seed was found to be $67.1 \% \mathrm{db}$.

\section{The Experimental Facilities}

Drying experiments were conducted by means of a laboratory fluidized bed dryer assisted by a modified domestic microwave oven $(900 \mathrm{~W})$ as illustrated in Fig. 1. The dryer was designed and fabricated in the department of agricultural machinery of Bu-Ali Sina University. This device was designed to dry samples while the temperature and velocity of air and microwave power were controlled. The drying chamber consisted of a Pyrex duct of 100 $\mathrm{mm}$ diameter and $200 \mathrm{~mm}$ height, which was placed within the microwave oven. A cylindrical Pyrex column, $90 \mathrm{~mm}$ in diameter (100 mm outside diameter) and $280 \mathrm{~mm}$ height was utilized as the fluidized bed drying chamber. The chamber was placed in a domestic microwave oven (Sharp R-I96T, Sharp Electronics, Bangkok, Thailand) with outside dimensions of $540 \times 330 \times 450 \mathrm{~mm}$. This oven was equipped with three power level settings of low $(270 \mathrm{~W})$, medium $(450 \mathrm{~W})$ and high $(630 \mathrm{~W})$, and was calibrated before experimentation. At the first phase of tests, fan speed was gradually increased using an inverter (Vincker VSD2, ABB Co., Taipei, Taiwan) and air velocity was recorded using a multifunction measurement device (Standard ST-8897, Standard instruments Co., Kowloon, Hong Kong). It consists of a vane-type digital anemometer with $\pm 0.1 \mathrm{~m} / \mathrm{s}^{1}$ accuracy. Three air velocities of $0.8,1.5$ and $2.3 \mathrm{~m} / \mathrm{s}$ were applied in the experiments. An electrical heating unit equipped with a thermostat $( \pm 1)$ was utilized to maintain different levels of drying air temperature of 40,55 and $70^{\circ} \mathrm{C}$. A schematic diagram of employed apparatus is shown in Fig. 1 .

Experimental Method and Drying Conditions 
A bulk of melon seeds (about $30 \pm 1 \mathrm{~g}$ ) was loaded in the dryer chamber and drying experiment was started. The melon seeds were thoroughly mixed in the dryer system and could be easily traced for any moisture content reductions during the drying processes. All experiments were carried out in triplicates.

Measurement of water loss from the samples was offline. Sample weighting (in at most 10 seconds) was implemented using a digital balance (AND GF-6000, Japan, $\pm 0.0001 \mathrm{~g}$ accuracy). The experiments were performed in combined fluidized bed dryer at three air temperatures of 40,55 and $70{ }^{\circ} \mathrm{C}$, three air velocity levels $(0.8,1.5$ and $2.3 \mathrm{~m} / \mathrm{s})$ and three microwave power levels $(270,450$, and $630 \mathrm{~W})$. After turning on the dryer, 30 min was the approximate time required to achieve the steady state. Several trials of the experiments were conducted to acquire data for moisture contents versus time. At the end of each drying period, when the moisture content of the melon seeds reached the equilibrium stage (no appreciable changes in three successive sample weighing), the exit air temperature profile remained at a nearly constant level. Drying was continued until final moisture content was converged to about the value of $5 \%$ (d.b.), which is acceptable equilibrium moisture at room conditions.

\section{Modeling of the Moisture Ratio}

The following equation was used to calculate the moisture ratio $(M R)$ of melon seed during the drying process:

$$
M R=\frac{M-M_{e}}{M_{b}-M_{e}}
$$

where $M R$ is the moisture ratio, $M$ is the moisture content at any time (\% d.b.); $M_{b}$ and $M_{e}$ are the initial and equilibrium moisture contents, respectively (\% d.b.).

Based on the pretest elucidations, $M_{e}$ values were relatively negligible compared to $M$ and $M_{b}$. Therefore, Eq. (1) was simplified as follows [16]:

$$
M R=\frac{M}{M_{b}}
$$

Statistical Modeling Procedure 
The non-linear regression analysis was performed using Curve Expert software (Ver. 1.4, Hyams Development, Los Angeles, CA) to determine the constants of the model. Five general models shown in Table 1 were fitted to the experimental data. Three criteria were adopted to evaluate the goodness of fit of each model. Correlation coefficient $\left(R^{2}\right)$, chi-square $\left(\chi^{2}\right)$ and root mean square error (RMSE) were adopted to determine the quality of the model fitness [13]:

$$
\begin{aligned}
& R^{2}=1-\frac{\sum_{i=1}^{N}\left[M R_{\exp , i}-M R_{p r e, i}\right]^{2}}{\sum_{k=1}^{N}\left[\frac{\sum_{k=1}^{n} M R_{p r e, i}}{N}-M R_{p r e, i}\right]^{2}} \\
& \chi^{2}=\frac{\sum_{i=1}^{N}\left(M R_{\exp , i}-M R_{p r e, i}\right)^{2}}{N-z}
\end{aligned}
$$

$$
R M S E=\left[\frac{1}{N} \sum_{i=1}^{N}\left(M R_{p r e, i}-M R_{\text {exp }, i}\right)^{2}\right]^{\frac{1}{2}}
$$

where $M R_{\text {exp }, i}$ is the experimental moisture ratio of $\mathrm{i}^{\text {th }}$ data, $M R_{p r e, i}$ is the predicted moisture ratio of $\mathrm{i}^{\text {th }}$ data, $N$ is the number of observations and $z$ is the number of drying constants.

Ultimately, the most suitable model to describe of drying characteristics of melon seed would be a model with the highest $R^{2}$ and the lowest $\chi^{2}$ and RMSE values [13].

\section{Calculation of Effective Diffusivity}

It has been accepted that the mass transfer of biological products in the falling rate period can be described by using Fick's second law of diffusion. Simplified equation of moisture diffusivity provides an approximate method to present a common quantitative comparison between different products in the aspect of moisture transfer since it can provide a description analysis for mean diffusion coefficient in the entire drying process [16]. To determine the effective moisture diffusivity ( $D_{\text {eff }}$ ), was used Equation (2) (for an infinite slab), which can be defined as follows [26]: 
$M R=\frac{8}{\pi^{2}} \sum_{n=0}^{\infty} \frac{1}{(2 n+1)^{2}} \exp \left(-\frac{(2 n+1)^{2} \pi^{2} t D_{e f f}}{4 L^{2}}\right)$

where $M R$ is the dimensionless moisture ratio; $D_{\text {eff }}$ is the effective diffusivity $\left(\mathrm{m}^{2} \mathrm{~s}^{-1}\right) ; n$ is positive integer, $t$ is drying time, and $L$ is the half thickness of the slab in samples (m). In practice, only the first term of the series in Eq. (6) is used, resulting in the following simplified form of the equation:

$\ln (M R)=\left(\frac{8}{\pi^{2}}\right) \exp \left(-\frac{\pi^{2} D_{\text {eff }} t}{4 L^{2}}\right)$

Calculation of Activation Energy

Considering that the effective diffusivity varies with temperature according to an Arrhenius type function [27,28]:

$D_{e f f}=D_{e}^{0} \exp \left(-\frac{E_{a}}{R T}\right)$

where $D_{e}{ }^{0}$ is the diffusivity for an infinite temperature $\left(\mathrm{m}^{2} / \mathrm{s}\right), \mathrm{E}_{\mathrm{a}}$ is the activation energy for moisture diffusion $(\mathrm{J} / \mathrm{mol}), R$ is the gas constant $(\mathrm{R}=8.31451 \mathrm{~J} /(\mathrm{mol} . \mathrm{K}))$ and $T$ is the drying temperature (expressed in Kelvin) [27,28], then:

$\ln \left(D_{e}\right)=\ln \left(D_{e}^{0}\right)+\left(-\frac{E_{a}}{R}\right) \frac{1}{T}$

Plotting $\ln \left(D_{e}\right)$ versus $(1 / T)$ a straight line is also obtained, with:

$$
\begin{aligned}
& \text { intercept }=\ln \left(D_{e}^{0}\right) \\
& \text { slope }=-\frac{E_{a}}{R}
\end{aligned}
$$

which allows estimating the values of the parameters in Equation (8): $D_{e}{ }^{0}$ and $E_{a}$.

Calculation of Shrinkage

Shrinkage is usually defined as the ratio of the final to initial volume of the drying sample. Many researchers have expressed shrinkage as a function of selected dimension changes of 
the samples [18]. In many computations it can be assumed that there is no shrinkage just for simplicity; nevertheless, shrinkage is never negligible in drying phenomena. Most of agricultural products shrink during drying; some of them shrink by more than $50 \%$ of their original dimensions depending upon the drying method and degree of drying [16]. Shrinkage of melon seed causes a significant variation in mass transfer phenomenon. As a result, the calculated value of the effective moisture diffusivity will be overestimated. For this reason, dimensional changes of the melon seed due to shrinkage should be calculated. Three dimensions of the melon seed in three directions were measured by means of a digital caliper. Geometric mean diameter of the melon seed can be calculated as follows noting that the shape is spheroid [29]:

$$
D=(A \times B \times C)^{\frac{1}{3}}
$$

where $D, A, B$ and $C$ are geometric mean, major, intermediate and minor diameters (m), respectively.

Melon seed volume before drying (initial volume) was computed using the following equation [30]:

$V_{0}=\frac{4}{3} \pi\left(\frac{D}{2}\right)^{3}$

where $V_{0}$ is the initial volume before drying $\left(\mathrm{m}^{3}\right)$.

Shrinkage of the samples was calculated using the following equation [17]:

$S_{b}=\frac{\left(V_{0}-V\right)}{V_{0}} \times 100$

where $S_{b}$ is shrinkage (\%) and $V$ is the final volume after drying $\left(\mathrm{m}^{3}\right)$.

\section{Results and discussion}

Drying Kinetics

In order to consider drying behavior, different drying curves of a hygroscopic product may be plotted, being the plot of moisture content versus time the more convenient. Fig. 2 illustrates the variations of moisture content against drying time for all temperature levels, microwave 
power levels and air velocities. The initial moisture content of the melon seed was $67.1 \%$ (db.) and they were dried to about $5 \%$ (db.). As can be seen, with increasing in air temperature $\left(40{ }^{\circ} \mathrm{C}\right.$ to $70{ }^{\circ} \mathrm{C}$ ), the drying time was diminished, and at higher temperature, due to the quick removal of moisture, the drying process was shorter. While increasing the microwave energy level (from $270 \mathrm{~W}$ to $630 \mathrm{~W}$ ) in the microwave assisted fluidized bed system, the drying time decreased dramatically. To be detailed, at the air velocity of $0.8 \mathrm{~m} / \mathrm{s}$ and $40{ }^{\circ} \mathrm{C}$ it took $150 \mathrm{~min}$ at $270 \mathrm{~W}$, and for the same air velocity but at $70{ }^{\circ} \mathrm{C}$ it took only 16 $\min$ at $630 \mathrm{~W}$. The decrease in drying time with increase in drying temperature may be due to increase in water vapor pressure within the melon seed, which increased the migration of moisture, especially as the drying occurs only in falling rate period [30]. Similar observation was reported for tomato slices [31]. The moisture ratio of melon seed decreased exponentially as the drying time increased. Continuous decline in moisture ratio means that diffusion governed the internal mass transfer [32]. Therefore, the water vapor concentration on the outer surface of the drying object reached the equilibrium conditions more rapidly at higher drying air temperature. Similar results were reported by other researchers for drying of apple [33] or green beans [34]. The combined effects of microwave power and drying air temperature on drying time are shown in Fig. 2. The results indicated that by increasing the drying air temperature and using microwave energy power as an assisting heat source, the values of drying rate or moisture diffusivity increased, probably due to the penetration of microwave energy into the sample and also due to the creation of a large vapor pressure difference between the center and the surface of the sample $[14,35]$. Similar results were reported by other researchers $[14,35]$.

\section{Mathematical Modeling}

The drying kinetics of melon seed at different bed conditions, air temperature and microwave power level was predicted using five mathematical models shown in Table 1 (Midilli et al. Newton, Aghbashloo et al. Page and Logistic), to evaluate their suitability based on the select criteria such as coefficient of determination $\left(R^{2}\right)$, chi-square $\left(\chi^{2}\right)$ and root mean square error (RMSE). Table 2 shows the quality of the fitting for the five models tested and the results demonstrated that the Aghbashloo et al. model, on average, succeeded comparatively to the others by corresponding to higher $R^{2}$ values for all temperature levels, while the $\chi^{2}$ and RMSE values were also found to be the lowest, thus meaning a good agreement with all 
experimental data. Generally, $R^{2}, \chi^{2}$ and $R M S E$ values of the Aghbashloo et al. model ranged from 0.9908 to $0.9999,0.0000$ to 0.0018 and 0.0228 to 0.8231 , respectively (Table 2). Consequently, Aghbashloo et al. model was selected as a suitable model to describe the thin layer drying behavior of melon seed in a microwave assisted fluidized bed dryer, and the results of the parameter estimation for this model are shown in Table 3. As the results imply, it was seen that the Aghbashloo et al. model provided a good fitness to experimental data on drying of melon seed at $70{ }^{\circ} \mathrm{C}$ and $1.5 \mathrm{~m} / \mathrm{s}$ and microwave power level of $630 \mathrm{~W}$ with the highest $\mathrm{R}^{2}$ of 0.99998 , the lowest $\chi^{2}$ of 0.00000 and RMSE of 0.0228 (Table 2). To validate the suitability of the model, the experimental and predicted drying characteristics were compared. Predicted values of moisture ratio by Aghbashloo et al. model were plotted against experimental data (Fig. 3). The $R^{2}$ value (0.9999) of this curve showed that the Aghbashloo et al. model is superior for prediction of melon seed drying behavior at $70{ }^{\circ} \mathrm{C}$ and $1.5 \mathrm{~m} / \mathrm{s}$ and microwave power level of $630 \mathrm{~W}$ (Fig. 3). This confirms the suitability of the models to represent the experimental results.

\section{Effective Moisture Diffusivity}

The determined values of effective moisture diffusivity $\left(D_{\text {eff }}\right)$ for all levels of air temperature, velocity and microwave power are exhibited in Fig.4. It can be seen that $D_{\text {eff }}$ values of the melon seed increased progressively for the same conditions of air temperature as applied microwave power was increased. This might be described by the enhanced heating energy, which would increase the activity of the water molecules leading to higher moisture diffusivity when samples were dried at higher microwave power. This effect is more intense for higher temperature levels. Many researchers have reported this phenomenon in their studies, such as [15] for peaches and [36] for plums. The values of $D_{\text {eff }}$ found in this research fall into the range of $6.51 \times 10^{-10}$ to $6.59 \times 10^{-9} \mathrm{~m}^{2} / \mathrm{s}$. Madamba et al. [37] reported that the $D_{\text {eff }}$ value for food materials is within the range of $10^{-11}$ to $10^{-9} \mathrm{~m}^{2} / \mathrm{s}$. Furthermore, the obtained results were in agreement with the results of [38] and [4]. The results indicate that the maximum value of $D_{\text {eff }}$ obtained at maximum air temperature $\left(70{ }^{\circ} \mathrm{C}\right)$ and maximum power level $(630 \mathrm{~W})$ for the fixed bed with $0.8 \mathrm{~m} / \mathrm{s}$ was $6.59 \times 10^{-9} \mathrm{~m}^{2} / \mathrm{s}$. Contrarily, the minimum $D_{\text {eff }}$ obtained was $6.52 \times 10^{-10} \mathrm{~m}^{2} / \mathrm{s}$ at the temperature of $40{ }^{\circ} \mathrm{C}$, power level of $270 \mathrm{~W}$ and also in the fixed bed with $0.8 \mathrm{~m} / \mathrm{s}$. 
Table 4 presents the values of activation energy calculated from the values of the effective diffusivity as a function of temperature for the different drying conditions. The values stand in the range from 27.6 to $45.3 \mathrm{~kJ} / \mathrm{mol}$, for fluid bead at $270 \mathrm{~W}$ power and fixed bed at $630 \mathrm{~W}$ power. It was observed a trend for the activation energy to be higher for fixed bed conditions, followed by semifluid bed and finally fluid bed. On the other hand, no constant trend was observed for the variation of activation energy with microwave power applied. Lüle and Koyuncu [39] evaluated the convective and microwave drying characteristics of Sorbus fruits and found that convective drying air temperature and microwave oven power levels influenced the total drying time as well as the requirements in terms of total energy and specific energy. Also Łechtańska et al. [40] studied the microwave- and infrared-assisted convective drying of green pepper and verified that convective drying assisted with both microwave and/or infrared radiation significantly shortened the drying time and saved energy consumption compared to pure convective drying.

The values for activation energy found in this work are within the same range of other values reported in literature, although in different drying conditions. The activation energy for apples at convective drying in the temperature range $30-60{ }^{\circ} \mathrm{C}$ was between 32.8 and 35.3 $\mathrm{kJ} / \mathrm{mol}$, depending on the variety [28]. The activation energy for the convective drying of pumpkin pulp was $33.7 \mathrm{~kJ} / \mathrm{mol}$ for temperatures between 30 and $70{ }^{\circ} \mathrm{C}$ [41], and for onion was $26.4 \mathrm{~kJ} / \mathrm{mol}$ for temperatures in the range $30-60{ }^{\circ} \mathrm{C}$ [42].

\section{Shrinkage Effect}

In order to show the effects of various parameters on the shrinkage of melon seed, several experiments were carried out under different operating conditions. The percentages of shrinkage in melon seed under microwave assisted fluidized bed dryer at different temperatures of 40,55 and $70{ }^{\circ} \mathrm{C}$ and power levels of 270,450 and $630 \mathrm{~W}$ are shown in Fig. 5. It was concluded that drying air temperature and microwave power level both showed significant effect on the melon seed shrinkage during the drying process. As it was expected, increasing the heating air temperature and microwave power resulted in increasing the degree of shrinkage of melon seed. Maximum shrinkage (46.99\%) was achieved at air temperature of $70{ }^{\circ} \mathrm{C}$, air velocity of $0.8 \mathrm{~m} / \mathrm{s}$ and microwave power of $630 \mathrm{~W}$. The lowest shrinkage value $(15.09 \%)$ was found at air temperature of $40{ }^{\circ} \mathrm{C}$, air velocity of $2.3 \mathrm{~m} / \mathrm{s}$ and microwave power of $270 \mathrm{~W}$. More intense shrinkage at higher temperatures and microwave power is due to faster mass transfer, so the created free space causes tension in the hawthorn tissue and 
therefore the product becomes more wrinkled [16, 18]. Similar results have been obtained for broad beans [16], and papaya [18]. When water is gradually removed from a foodstuff, a pressure unbalance is generated between the inner section of the material and the external pressure creates contracting stresses that lead to material shrinkage or collapse, changes in shape and occasionally cracking of the product [17]. At higher microwave power, much severe shrinkage may occur owing to the fact that high radiation power engenders more heat in melon seed samples. Similar behavior has been observed on potato drying [43] and drying of carrot and garlic [44].

\section{Conclusion}

Five empirical models were utilized to prognosticate the drying kinetics of melon seed, from which the Aghbashloo model was the best, showing high values of $\mathrm{R}^{2}$ (from 0.99294 to 0.99998) in addition with low values of RMSE (from 0.02289 to 0.82316), thus being indicated to predict the drying kinetics for all the conditions tested. The Moisture diffusivity values of the melon seed were intensively increased as higher microwave power was applied. The minimum value of $D_{\text {eff }}$ obtained was $6.59 \times 10^{-9} \mathrm{~m}^{2} / \mathrm{s}$, respectively for the fixed bed with $0.8 \mathrm{~m} / \mathrm{s}, 70{ }^{\circ} \mathrm{C}$ and $630 \mathrm{~W}$ while the minimum value was $6.51 \times 10^{-10} \mathrm{~m}^{2} / \mathrm{s}$ for the fixed bed with $0.8 \mathrm{~m} / \mathrm{s}, 40{ }^{\circ} \mathrm{C}$ and $270 \mathrm{~W}$. The activation energy varied from 27.6 to $45.3 \mathrm{~kJ} / \mathrm{mol}$, showing a trend for increasing as the air velocity diminished.

Shrinkage percentage increased with microwave power and air temperature, so that the highest shrinkage was observed at air temperature of $70{ }^{\circ} \mathrm{C}$, air velocity of $0.8 \mathrm{~m} / \mathrm{s}$ and microwave power of $630 \mathrm{~W}$.

\section{Acknowledgements}

The authors would like to thank Bu-Ali Sina University for financial support of this study.

\section{References}

1. O.O. Ajibola, S.E. Eniyemo, O.O. Fasina, K.A. Adeeko, Mechanical expression of oil from melon seeds. J. Agr. Eng. Res. 45, 45-53 (1990)

2. S.A. Bankole, O.A. Lawal, A. Adebanjo, Storage practises and aflatoxin B1 contamination of 'egusi' melon seed in Nig. Tropical Science 44, 150-153 (2004a)

3. S.A. Bankole, Moisture content, mould invasion and seed germinability of stored melon. Mycopathologia 122, 123-126 (1993) 
4. I. Doymaz, Air-drying characteristics of tomatoes. J. Food Eng. 78, 1291-1297 (2007)

5. I. Golpour, R. Amiri Chayjan, J. Amiri Parian, J. Khazaei, Prediction of paddy moisture content during thin layer drying using machine vision and artificial neural networks. Jast 17, 287-298 (2015)

6. L. Momenzadeh, A. Zomorodian, D. Mowla, Experimental and theoretical investigation of shelled corn drying in a microwave-assisted fluidized bed dryer using artificial neural network. Food Bioprod. Process. 89, 15-21 (2011)

7. M.S. Hatamipour, D. Mowla, Experimental and theoretical investigation of drying of carrots in a fluidized bed with energy carrier. Dry. Technol. 21, 83-101. (2003)

8. G.P. Sharma, S. Prasad, Specific energy consumption in microwave drying of garlic cloves. Energy 31, 1921-1926 (2006)

9. M.E.C. Oliveira, A.S. Franca, Finite element analysis of microwave heating of solid. Int. Comm. Heat Mass Transfer 27(4), 527-536 (2000)

10. G.R. Askari, Z. Emam-Djomeh, S.M. Mousavi, Heat and mass transfer in apple cubes in a microwave-assisted fluidized bed drier. Food Bioprod. Process. 91(3), 207215 (2013)

11. M.O. Fakhouri, H.S. Ramaswamy, Temperature uniformity of microwave heated foods as influenced by product type and composition. Food Res. Int. 26(1), 89-95 (1993)

12. K.G. Ayappa, H.T. Davis, E.A. Davis, J. Gordon, Two-dimensional finite element analysis of microwave heating. AIChe Journal, 38(10), 1577-1592 (1992)

13. R. Amiri Chayjan, M. Kaveh, S. Khayati, Modeling drying characteristics of hawthorn fruit under microwave-convective conditions. J. Food Process. Pres. 39(3), 239-253 (2015)

14. L. Momenzadeh, A. Zomorodian, D. Mowla, Applying artificial neural network for drying time prediction of green pea in a microwave assisted fluidized bed dryer. JAST 14, 513-522 (2012)

15. A.R.P. Kingsly, R.K. Goyal, M.R. Manikantan, S.M. Ilyas, Effects of pretreatments and drying air temperature on drying behavior of peach slice. Int. J. Food Sci. Technol. 42, 65-69 (2007)

16. G. Hashemi, D. Mowla, M. Kazemeini, Moisture diffusivity and shrinkage of broad beans during bulk drying in an inert medium fluidized bed dryer assisted by dielectric heating. J. Food Eng. 92, 331-338 (2009) 
17. L. Mayor, A.M. Sereno, Modelling shrinkage during convective drying of food materials: a review. J. Food Eng. 61, 373-386 (2004)

18. L.E. Kurozawa, M.D. Hubinger, K.J. Park, Glass transition phenomenon on shrinkage of papaya during convective drying. J. Food Eng. 108, 43-50 (2012)

19. B. Suresh, A. Kaur, M. R. Manikantan M R, Moisture dependant physical properties of sunflower seed (Psh 569). Int. J. Eng. Sci. 2(8): 23-27 (2013)

20. M. Shakeri, R. Khodabakhshian. The physical attributes of safflower seed as a function of moisture content, variety and size. Electronic J. Polish Agric. Universities 14(3), 1-10 (2011).

21. R. Khodabkhshian, B. Emadi, M.H.A. Fard. Gravimetrical properties of sunflower seeds and kernels. World Applied Sci. J. 8(1), 119-128 (2010)

22. AOAC, Official method of analysis.13rd edn. Association of Official Analytical Chemists, Washington, DC. (1980)

23. M. Aghabashlo, M.H. Kianmehr, A. Arabhosseini, Performance analysis of drying of carrot slices in a semi-industrial continuous band dryer. J. Food Eng. 91, 99-108 (2009)

24. S.M. Henderson, Progress in developing the thin-layer drying equation. Trans. ASAE 17, 1167-1168 (1974)

25. A. Cihan, K. Kahveci, O. Hacihafizoglu, Modeling of intermittent drying of thin layer rough rice. J. Food Eng. 79, 293-298 (2007)

26. E.K. Akpinar, Determination of suitable thin layer drying curve model for some vegetables and fruits. J. Food Eng. 73, 75-84 (2006)

27. N.R. Swami Hulle, P.S. Rao, Effect of High Pressure Pre-treatments on Structural and Dehydration Characteristics of Aloe Vera (Aloe barbadensis Miller) cubes. Dry. Tech. 34(1), 105-118 (2016)

28. A.C. Cruz, R.P.F Guiné, J.C. Gonçalves, Drying Kinetics and Product Quality for Convective Drying of Apples (cvs. Golden Delicious and Granny Smith). Int. J. Fruit Sci. 15(1), 54-78 (2015)

29. N.N. Mohsenin, Physical characteristics: physical properties of plant and animal materials. Gordon and Breach Science Publisher (1996)

30. M. Kaveh, R. Amiri Chayjan, M. Esna-Ashari.. Thermal and physical properties modelling of terebinth fruit (Pistacia atlantica L.) under solar drying. Res. Agr. Eng. 61(4), 150-161 (2015) 
31. J. Khazaei, G.R. Chegini, M. Bakhshiani, A novel alternative method for modeling the effects of air temperature and slice thickness on quality and drying kinetics of tomato slices: Superposition Technique. Dry. Technol. 26, 759-775 (2008)

32. A.K. Haghi, N. Amanifard, Analysis of heat and mass transfer during microwave drying of food products. Braz. J. Chem. Eng. 25, 491-501 (2008)

33. H. Feng, J. Tang, R.P. Cavalieri, Dielectric Properties of Dehydrated Apples as Affected by Moisture and Temperature. Trans. ASAE 45, 129-135 (2001)

34. B. Abbasi Souraki, D. Mowla, Axial and radial moisture diffusivity in bed dryer with energy carrier: modeling with and without shrinkage. J. Food Eng. 88, 9-19 (2008)

35. B. Abbasi Souraki, D. Mowla, Simulation of drying Behavior of a small spherical foodstuff in a microwave assisted fluidized bed of inert Particles. Food Res. Int. 41, 255-265 (2008)

36. R.K. Goyal, A.R.P. Kingsly, M.R. Manikantan, S.M. Ilyas, Mathematical modeling of thin layer drying kinetics of plum in a tunnel dryer. J. Food Eng. 79, 176-180 (2007)

37. P.S. Madamba, R.H. Driscoll, K.A. Buckle, Enthalpy- entropy compensation models for sorption and browning of garlic. J. Food Eng. 28,109-119 (1996)

38. K. Sacilik, R. Keskin, A.K. Elicin, Mathematical modeling of solar tunnel drying of thin layer organic tomato. J. Food Eng. 73, 231-238 (2006)

39. F. Lüle, T. Koyuncu, Convective and microwave drying characteristics of sorbus fruits (Sorbus domestica L.). Procedia - Soc. Behav. Sci. 195(3), 2634-2643 (2015)

40. J.M. Łechtańska, J. Szadzińska, S.J. Kowalski, Microwave- and infrared-assisted convective drying of green pepper: Quality and energy considerations. Chem. Eng. Proc.: Process Intens., 98, 155-164 (2015)

41. R.P.F. Guiné, S. Pinho, M.J. Barroca, Study of the convective drying of pumpkin (Cucurbita maxima). Food Bioprod. Process. 89, 422-428 (2011)

42. C.L. Mota, C. Luciano, A. Dias, M.J. Barroca, R.P.F. Guiné. Convective drying of onion: Kinetics and nutritional evaluation. Food Bioprod. Process. 88, 115-123 (2010)

43. N. Wang, J.G. Brennan, Changes in structure, density and porosity of potato during dehydration. J. Food Eng. 24, 61-76 (1995)

44. B. Taner, I. Filiz, E. Seda, Y. Hasan, Effects of microwave and infrared drying on the quality of carrot and garlic. Eur. Food Res. Technol. 218, 68-73 (2003) 
Table 1 Mathematical models applied to drying curves

No Model name Model equation

References

1 Aghbashloo et al. $\quad M R=\exp (-a t /(1+b t))$

Aghbashloo et al. [23]

2 Midilli et al.

$M R=a \exp \left(-k t^{n}\right)+b t$

Sacilik et al. [8]

3 Page

$M R=\exp \left(-k t^{n}\right)$

Amiri chayjan et al. [13]

$4 \quad$ Newton

$M R=\exp (-k t)$

Henderson [24]

$5 \quad$ Logistic

$M R=a /(1+b \exp (k t))$

Cihan et al. [25] 
Table 2 Statistical criteria obtained from fitting the five models to the experimental data of melon seed drying kinetics

\begin{tabular}{|c|c|c|c|c|c|c|c|c|c|c|c|}
\hline \multirow[t]{2}{*}{ Model name } & \multirow{2}{*}{$\begin{array}{c}\text { Air } \\
\text { velocity } \\
(\mathrm{m} / \mathrm{s})\end{array}$} & \multirow{2}{*}{$\begin{array}{l}\text { Microwave } \\
\text { power } \\
(\mathrm{W})\end{array}$} & \multicolumn{3}{|c|}{$R^{2}$} & \multicolumn{3}{|c|}{$\chi^{2}$} & \multicolumn{3}{|c|}{ RMSE } \\
\hline & & & $40{ }^{\circ} \mathrm{C}$ & $55^{\circ} \mathrm{C}$ & $70{ }^{\circ} \mathrm{C}$ & $40{ }^{\circ} \mathrm{C}$ & $55{ }^{\circ} \mathrm{C}$ & $70{ }^{\circ} \mathrm{C}$ & $40{ }^{\circ} \mathrm{C}$ & $55^{\circ} \mathrm{C}$ & $70{ }^{\circ} \mathrm{C}$ \\
\hline \multirow{9}{*}{ Aghbashloo et al. } & \multirow{3}{*}{0.8} & 270 & 0.99294 & 0.99929 & 0.99947 & 0.00174 & 0.00130 & 0.00082 & 0.24199 & 0.21332 & 0.16204 \\
\hline & & 450 & 0.99886 & 0.99979 & 0.99746 & 0.00112 & 0.00010 & 0.00185 & 0.27721 & 0.10005 & 0.32597 \\
\hline & & 630 & 0.99720 & 0.99971 & 0.99998 & 0.00070 & 0.00026 & 0.00001 & 0.23448 & 0.11674 & 0.02562 \\
\hline & \multirow{3}{*}{1.5} & 270 & 0.99088 & 0.99954 & 0.99931 & 0.00026 & 0.00087 & 0.00038 & 0.82316 & 0.14735 & 0.17060 \\
\hline & & 450 & 0.99849 & 0.99997 & 0.99993 & 0.00079 & 0.00000 & 0.00005 & 0.30308 & 0.03139 & 0.05220 \\
\hline & & 630 & 0.99977 & 0.99993 & 0.99998 & 0.00089 & 0.00002 & 0.00000 & 0.11373 & 0.05528 & 0.02289 \\
\hline & \multirow{3}{*}{2.3} & 270 & 0.99368 & 0.99721 & 0.99889 & 0.00172 & 0.00059 & 0.00007 & 0.38338 & 0.28649 & 0.21972 \\
\hline & & 450 & 0.99952 & 0.99989 & 0.99639 & 0.00050 & 0.00000 & 0.00031 & 0.06734 & 0.06015 & 0.12579 \\
\hline & & 630 & 0.99951 & 0.99996 & 0.99989 & 0.00156 & 0.00001 & 0.00010 & 0.11603 & 0.03449 & 0.06368 \\
\hline \multirow{11}{*}{ Newton } & \multirow{3}{*}{0.8} & 270 & 0.55891 & 0.79761 & 0.99530 & 0.44750 & 0.16840 & 0.00300 & 5.87005 & 3.60094 & 0.48062 \\
\hline & & 450 & 0.77518 & 0.94127 & 0.99642 & 0.19780 & 0.03717 & 0.00949 & 3.90264 & 1.69195 & 0.47547 \\
\hline & & 630 & 0.83297 & 0.96963 & 0.00293 & 0.12963 & 0.01870 & 0.00464 & 3.15935 & 1.19995 & 0.14257 \\
\hline & \multirow{3}{*}{1.5} & 270 & 0.57059 & 0.93697 & 0.00026 & 0.41460 & 0.03942 & 0.08978 & 5.65015 & 1.74222 & 1.03194 \\
\hline & & 450 & 0.82102 & 0.98504 & 0.01383 & 0.14100 & 0.00852 & 0.00650 & 3.29499 & 0.81029 & 0.70762 \\
\hline & & 630 & 0.87888 & 0.98693 & 0.99106 & 0.08970 & 0.00774 & 0.00525 & 2.62809 & 0.77239 & 0.63617 \\
\hline & \multirow{3}{*}{2.3} & 270 & 0.81452 & 0.86616 & 0.98010 & 0.12990 & 0.09334 & 0.01127 & 3.16264 & 2.68089 & 0.93167 \\
\hline & & 450 & 0.88567 & 0.98140 & 0.98767 & 0.08567 & 0.01062 & 0.00741 & 2.56838 & 0.90429 & 0.75536 \\
\hline & & 630 & 0.90839 & 0.99477 & 0.99842 & 0.06694 & 0.00269 & 0.00089 & 2.27032 & 0.45587 & 0.26192 \\
\hline & \multirow[b]{2}{*}{0.8} & 270 & 0.89896 & 0.87520 & 0.99002 & 0.00977 & 0.00919 & 0.00147 & 0.86739 & 0.84120 & 0.33643 \\
\hline & & 450 & 0.87087 & 0.94379 & 0.99464 & 0.01321 & 0.03558 & 0.00293 & 1.00854 & 1.65519 & 0.47498 \\
\hline \multirow{5}{*}{ Logistic } & \multirow{5}{*}{1.5} & 630 & 0.85569 & 0.94183 & 0.99996 & 0.11199 & 0.00422 & 0.00001 & 2.93653 & 0.57003 & 0.03842 \\
\hline & & 270 & 0.86483 & 0.94001 & 0.97564 & 0.02258 & 0.00518 & 0.01340 & 1.31858 & 0.63155 & 1.01577 \\
\hline & & 450 & 0.86879 & 0.98104 & 0.98861 & 0.02235 & 0.00117 & 0.00647 & 1.31185 & 0.30040 & 0.70582 \\
\hline & & 630 & 0.88485 & 0.98719 & 0.99998 & 0.08520 & 0.00759 & 0.00012 & 2.56132 & 0.76468 & 0.09652 \\
\hline & & 270 & 0.92784 & 0.94423 & 0.94598 & 0.01144 & 0.00715 & 0.00291 & 0.93855 & 0.74199 & 0.47336 \\
\hline
\end{tabular}


Table 2 Continuation

\begin{tabular}{|c|c|c|c|c|c|c|c|c|c|c|c|}
\hline \multirow{2}{*}{ Model name } & \multirow{2}{*}{$\begin{array}{c}\text { Air } \\
\text { velocity } \\
(\mathrm{m} / \mathrm{s})\end{array}$} & \multirow{2}{*}{$\begin{array}{c}\text { Microwave } \\
\text { power } \\
(\mathrm{W})\end{array}$} & \multicolumn{3}{|c|}{$\mathrm{R}^{2}$} & \multicolumn{3}{|c|}{$\chi^{2}$} & \multicolumn{3}{|c|}{ RMSE } \\
\hline & & & $40{ }^{\mathrm{O}} \mathrm{C}$ & $55^{\circ} \mathrm{C}$ & $70{ }^{\circ} \mathrm{C}$ & $40{ }^{\mathrm{O}} \mathrm{C}$ & $55^{\circ} \mathrm{C}$ & $70{ }^{\circ} \mathrm{C}$ & $40{ }^{\mathrm{O}} \mathrm{C}$ & $55^{\circ} \mathrm{C}$ & $70{ }^{\circ} \mathrm{C}$ \\
\hline & 2.3 & 450 & 0.89274 & 0.98187 & 0.98758 & 0.08030 & 0.01030 & 0.00730 & 2.48658 & 0.89056 & 0.75014 \\
\hline & & 630 & 0.85156 & 0.99998 & 0.99843 & 0.01632 & 0.00009 & 0.00088 & 1.12100 & 0.08731 & 0.26104 \\
\hline & & 270 & 0.99640 & 0.99759 & 0.99960 & 0.00124 & 0.00048 & 0.00025 & 0.50899 & 0.19324 & 0.13957 \\
\hline \multirow{8}{*}{ Midili et al } & 0.8 & 450 & 0.99787 & 0.99951 & 0.99862 & 0.00053 & 0.00003 & 0.00000 & 0.20334 & 0.05508 & 0.01277 \\
\hline & & 630 & 0.99753 & 0.99875 & 0.99999 & 0.00041 & 0.00009 & 0.00001 & 0.17961 & 0.83290 & 0.29100 \\
\hline & & 270 & 0.99740 & 0.99706 & 0.99960 & 0.000826 & 0.00026 & 0.00038 & 0.45219 & 0.13957 & 0.17105 \\
\hline & 1.5 & 450 & 0.99713 & 0.99960 & 0.80174 & 0.00047 & 0.00000 & 0.00234 & 0.19164 & 0.02039 & 0.72447 \\
\hline & & 630 & 0.99790 & 0.99980 & 0.99882 & 0.00026 & 0.00001 & 0.00002 & 0.14365 & 0.03052 & 0.04030 \\
\hline & & 270 & 0.99116 & 0.99966 & 0.99980 & 0.00140 & 0.00004 & 0.00000 & 0.42832 & 0.5760 & 0.02770 \\
\hline & 2.3 & 450 & 0.99805 & 0.99996 & 0.99993 & 0.00027 & 0.00000 & 0.00003 & 0.14551 & 0.01906 & 0.05515 \\
\hline & & 630 & 0.99617 & 0.99995 & 0.99998 & 0.00042 & 0.00001 & 0.00007 & 0.27983 & 0.0087 & 0.02770 \\
\hline \multirow{9}{*}{ Page } & & 270 & 0.99494 & 0.99356 & 0.99872 & 0.00715 & 0.00059 & 0.00034 & 0.36603 & 0.31638 & 0.25127 \\
\hline & 0.8 & 450 & 0.99554 & 0.99868 & 0.99661 & 0.00099 & 0.00013 & 0.00138 & 0.29392 & 0.08775 & 0.37742 \\
\hline & & 630 & 0.99587 & 0.99637 & 0.99997 & 0.00371 & 0.00017 & 0.00000 & 0.23249 & 0.14230 & 0.03163 \\
\hline & & 270 & 0.99723 & 0.99694 & 0.99286 & 0.00880 & 0.00028 & 0.00037 & 0.25882 & 0.14231 & 0.17106 \\
\hline & 1.5 & 450 & 0.99524 & 0.99907 & 0.99998 & 0.00119 & 0.00001 & 0.00003 & 0.24679 & 0.06625 & 0.00277 \\
\hline & & 630 & 0.99302 & 0.99993 & 0.99998 & 0.00003 & 0.00016 & 0.00003 & 0.26178 & 0.01618 & 0.04474 \\
\hline & & 270 & 0.99911 & 0.99944 & 0.99891 & 0.00000 & 0.00442 & 0.00194 & 0.36392 & 0.07393 & 0.21440 \\
\hline & 2.3 & 450 & 0.99644 & 0.99986 & 0.99947 & 0.00035 & 0.00005 & 0.00006 & 0.19699 & 0.02244 & 0.15574 \\
\hline & & 630 & 0.99573 & 0.99997 & 0.99980 & 0.00035 & 0.00001 & 0.00450 & 0.34658 & 0.03618 & 0.08775 \\
\hline
\end{tabular}


Table 3 Model parameters estimated for the different drying conditions

\begin{tabular}{|c|c|c|c|c|c|c|c|c|}
\hline \multirow[t]{2}{*}{ Model name } & \multirow{2}{*}{$\begin{array}{c}\text { Air } \\
\text { velocity } \\
(\mathrm{m} / \mathrm{s})\end{array}$} & \multirow{2}{*}{$\begin{array}{c}\text { Microwave } \\
\text { power } \\
\text { (W) }\end{array}$} & \multicolumn{2}{|c|}{$40^{\circ} \mathrm{C}$} & \multicolumn{2}{|c|}{$55^{\circ} \mathrm{C}$} & \multicolumn{2}{|c|}{$70^{\circ} \mathrm{C}$} \\
\hline & & & $\mathrm{a}$ & $\mathrm{b}$ & $\mathrm{a}$ & $\mathrm{b}$ & $\mathrm{a}$ & $\mathrm{b}$ \\
\hline \multirow{9}{*}{ Aghbashloo et al. } & \multirow{3}{*}{0.8} & 270 & 31.2246 & 13.1580 & 19.5767 & 7.5299 & 3.6929 & 0.3889 \\
\hline & & 450 & 19.1942 & 7.4470 & 9.6401 & 3.0320 & 4.3371 & 0.5334 \\
\hline & & 630 & 16.0276 & 6.0186 & 7.8636 & 2.0553 & 3.1723 & 0.1667 \\
\hline & \multirow{3}{*}{1.5} & 270 & 27.5069 & 11.8128 & 9.2447 & 2.9614 & 6.1806 & 1.5823 \\
\hline & & 450 & 18.6452 & 7.0784 & 5.6811 & 1.1944 & 6.8709 & 1.6566 \\
\hline & & 630 & 15.8479 & 5.6647 & 5.9878 & 1.2051 & 6.8755 & 1.5862 \\
\hline & \multirow{3}{*}{2.3} & 270 & 12.4011 & 5.0175 & 12.9093 & 4.8030 & 5.7796 & 1.3399 \\
\hline & & 450 & 14.0307 & 4.8873 & 5.6179 & 1.2918 & 5.6179 & 1.2918 \\
\hline & & 630 & 14.2930 & 4.8181 & 4.0336 & 0.6056 & 3.4285 & 0.3174 \\
\hline
\end{tabular}

Table 4 Calculation of activation energy for different experimental conditions

\begin{tabular}{|c|c|c|c|c|}
\hline $\begin{array}{l}14 \\
\text { Drying conditions }\end{array}$ & $\begin{array}{l}\text { Microwave } \\
\text { Power } \\
(W)\end{array}$ & $\begin{array}{c}\mathbf{D}_{\mathrm{e}}{ }^{\mathbf{2}} \\
\left(\mathbf{m}_{2} / \mathbf{s}\right)\end{array}$ & $\begin{array}{c}\text { Ea } \\
(\mathrm{kJ} / \mathbf{m o l})\end{array}$ & $\begin{array}{l}\text { Regression } \\
\text { coefficient } \\
\text { (R) }\end{array}$ \\
\hline \multirow{3}{*}{$\begin{array}{l}16 \\
\text { Fixed bed } \\
(\mathbb{D} 78 \mathrm{~m} / \mathrm{s})\end{array}$} & 270 & $1.42 \times 10^{-2}$ & 44.0 & 0.9984 \\
\hline & 450 & $1.01 \times 10^{-2}$ & 42.1 & 0.9999 \\
\hline & 630 & $5.31 \times 10^{-2}$ & 45.3 & 0.9998 \\
\hline \multirow{3}{*}{$\begin{array}{l}18 \\
\text { Semi fluid bed } \\
(19.5 \mathrm{~m} / \mathrm{s})\end{array}$} & 270 & $8.77 \times 10^{-5}$ & 30.2 & 0.9691 \\
\hline & 450 & $5.58 \times 10^{-4}$ & 34.2 & 0.9899 \\
\hline & 630 & $1.05 \times 10^{-4}$ & 28.4 & 0.9966 \\
\hline \multirow{3}{*}{$\begin{array}{l}\text { Fluid bed } \\
21.3 \mathrm{~m} / \mathrm{s}) \\
22\end{array}$} & 270 & $4.26 \times 10^{-5}$ & 27.6 & 0.9984 \\
\hline & 450 & $4.5 \times 10^{-4}$ & 33.1 & 0.9999 \\
\hline & 630 & $1.09 \times 10^{-2}$ & 41.1 & 0.9998 \\
\hline
\end{tabular}




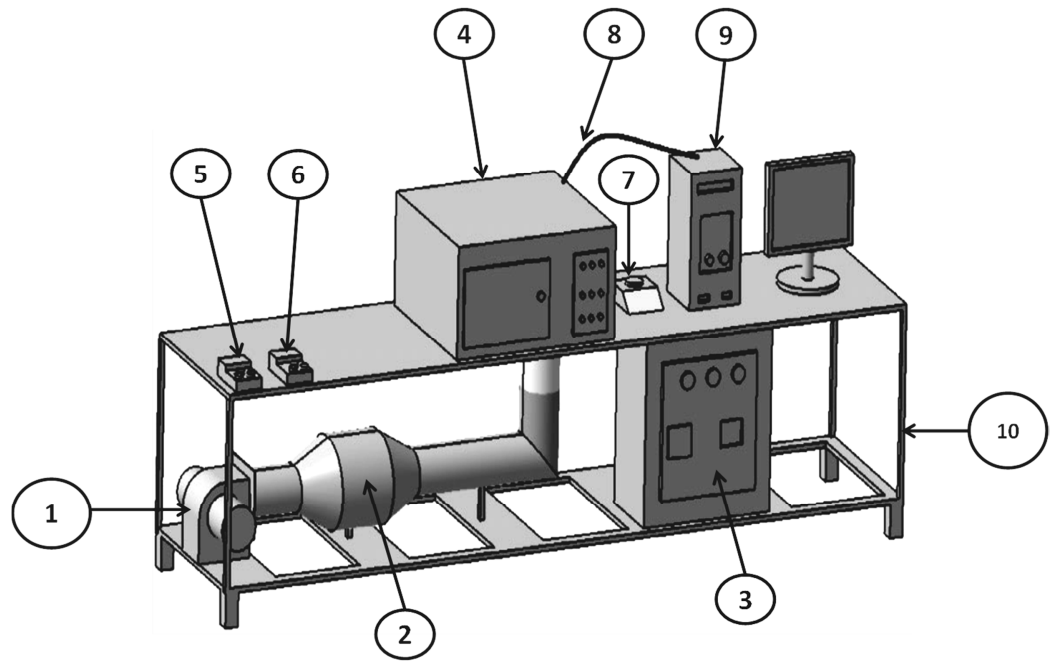

Fig. 1 Schematic diagram of laboratory scale microwave convection dryer: (1) fan and 32 electrical motor, (2) electrical heater, (3) inverter and thermostat, (4) drying chamber, (5) 33 thermometer, (6) hygrometer, (7) precision balance, (8) air velocity sensor, (9) computer, 34 (10) chassis 

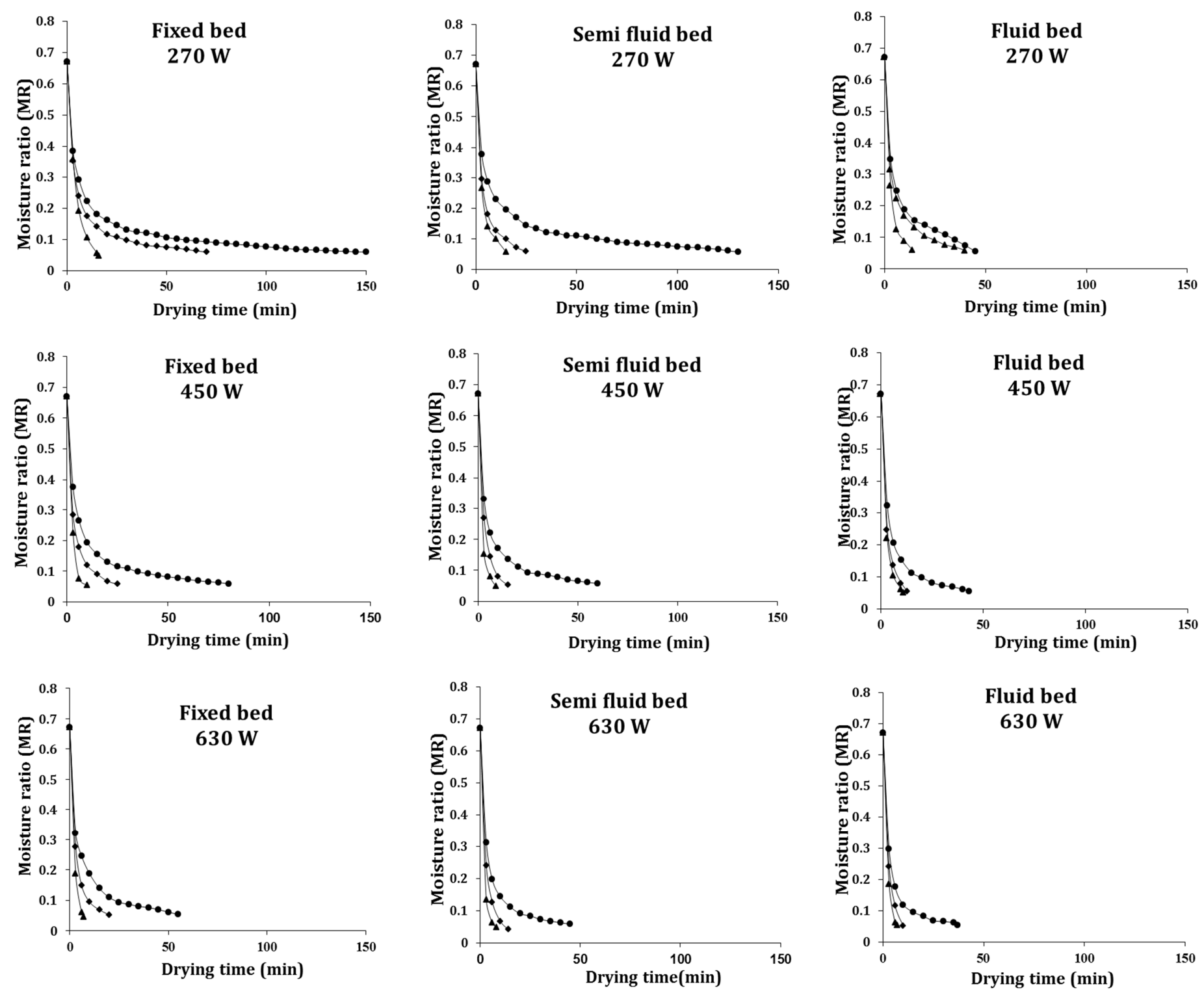

Fig. 2 Effect of drying air temperature on drying time of melon seed at different microwave 50 power levels $(270,450$, and $630 \mathrm{~W})$ and various air temperatures $\left(\bullet 40, \bullet 55\right.$ and $\left.\boldsymbol{\Delta} 70{ }^{\circ} \mathrm{C}\right) . \quad 51$ The air velocities were $0.8 \mathrm{~m} / \mathrm{s}$ in the fixed bed, $1.5 \mathrm{~m} / \mathrm{s}$ in the semi fluid bead and $2.3 \mathrm{~m} / \mathrm{s}$ in 52 the fluid bed. 


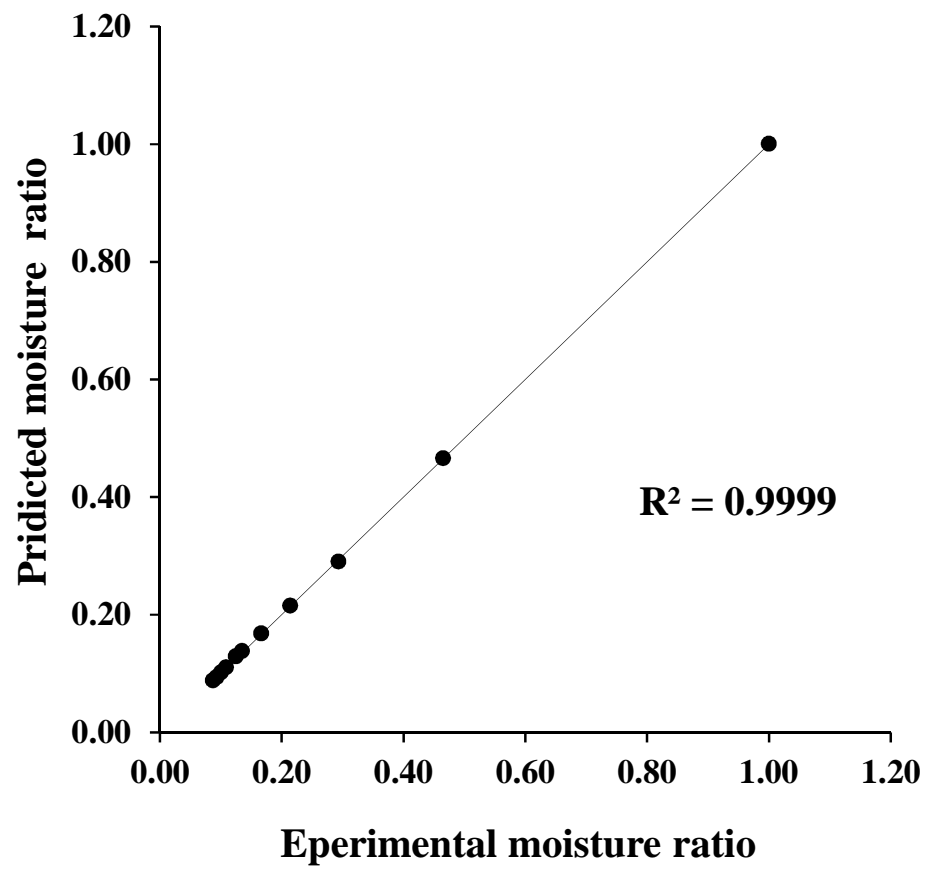

Fig. 3 Linear fit between predicted moisture ratio and experimental values (at $70{ }^{\circ} \mathrm{C}$ and $1.5 \quad 69$ $\mathrm{m} / \mathrm{s}$ and microwave power level of $630 \mathrm{~W}$ ) of Aghbashloo et al. model for thin layer drying 70 $\begin{array}{ll}\text { of melon seed } & 71\end{array}$ 

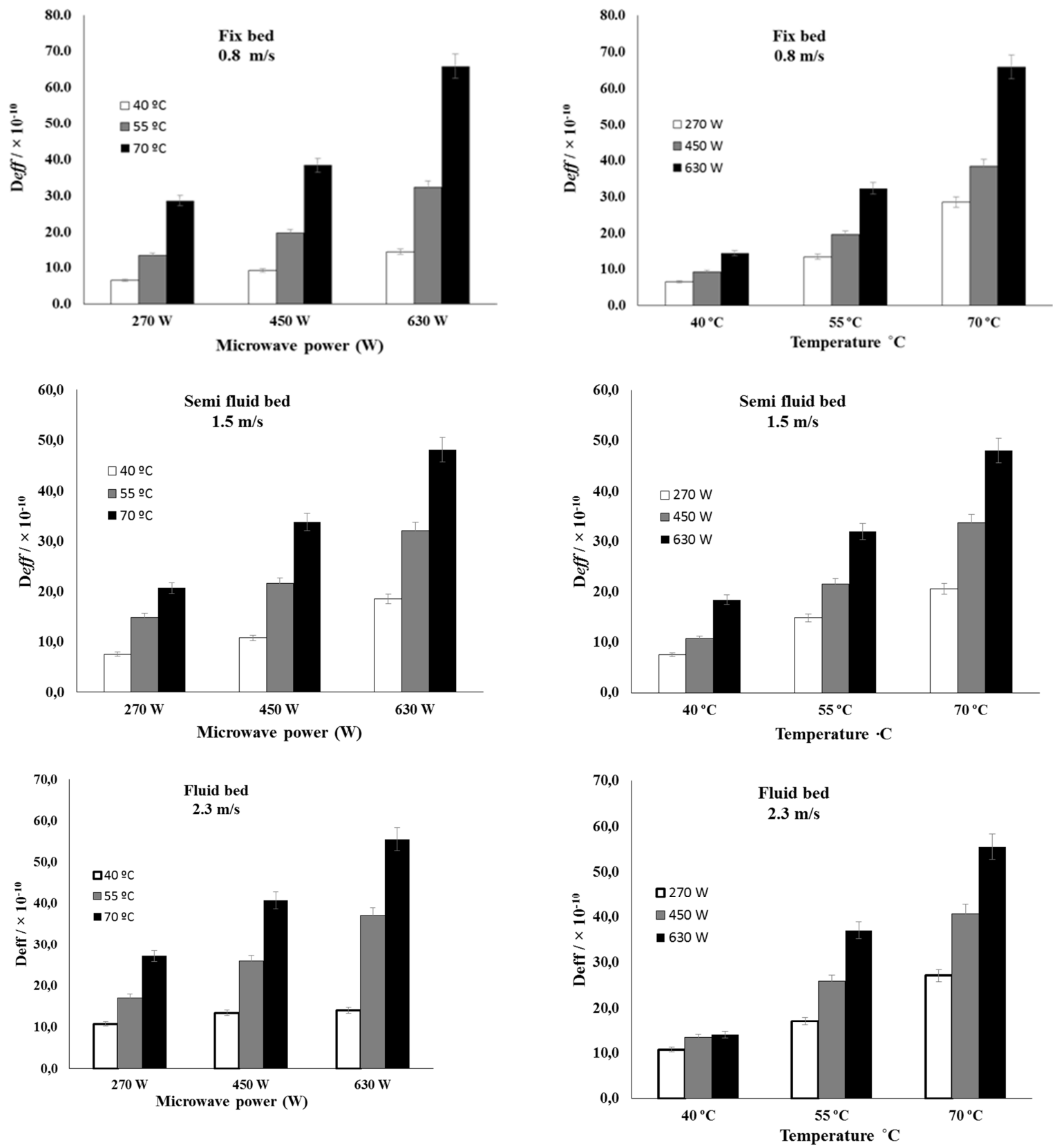

Fig. $4 D_{\text {eff }}$ versus microwave power and air temperature for drying melon seed. 


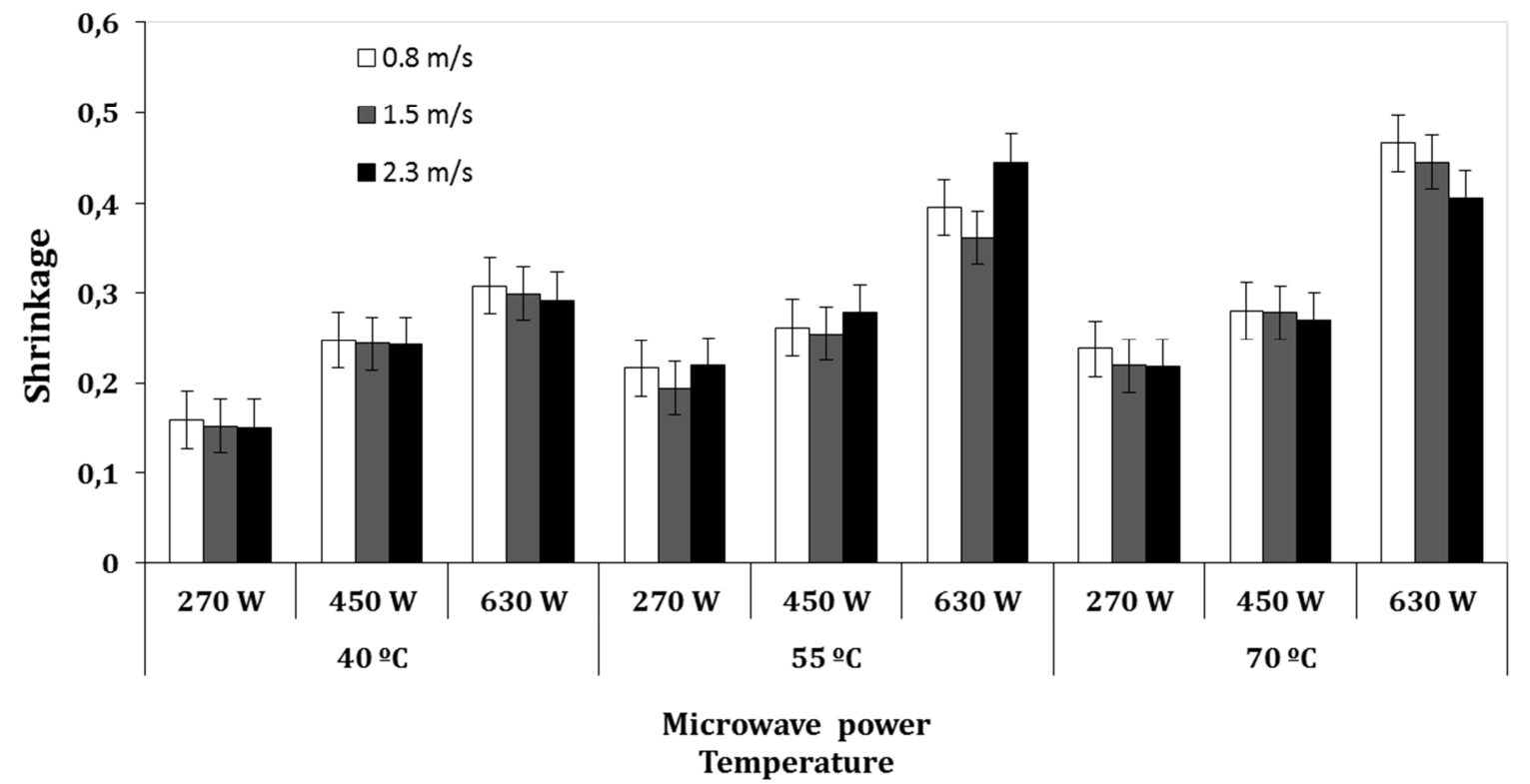

Fig. 5 Variation of shrinkage with air temperature and microwave power at different air 100 velocities for melon seed 